\title{
Total Factor Productivity and Supply- Demand Gap Analysis of Wheat in Sub-tropics of Jammu Region of Jammu and Kashmir
}

\section{Rakshanda Malik, Sudhakar Dwivedi*, Rajinder Peshin and Anil Bhat}

Sher-e-Kashmir University of Agricultural Sciences and Technology of Jammu, Chatha, India

*Corresponding author: dwivedi.sudhakar@gmail.com

Received: $12-08-2020$

Revised: $19-10-2020$

Accepted: $23-11-2020$

ABSTRACT

A study to assess Total Factor Productivity and Supply Demand Gap Analysis of Wheat in Subtropics of Jammu Region was conducted in Jammu and Kathua districts of J\&K UT during the agricultural year 2018-19. The results related to cost and returns revealed that per hectare cost of cultivation for wheat was worked out to be ₹ 41750.70, ₹ 44351.05, ₹ 46273.08, ₹ 44996.93 for Akhnoor, Marh, Marheen and Barnoti with an overall average of ₹ 44342.94. The per hectare gross returns of wheat cultivation of Akhnoor, Marh, Mahreen and Barnoti were ₹ 67975.00 , ₹ 61182.00 , ₹ 59630.00 and ₹ 54180.00 with an average return of 604741.75 respectively. The cost cultivation of wheat was found to be highest (₹ 46273.08/ha) in Mahreen block of Kathua district with an overall average of ₹ 44342.94. Out of all the inputs used, the expenditure incurred on machine labor was found to be highest (₹ 10031.14/ha) which was 40.93 percent of operational cost. The cost structure revealed that cost $\mathrm{C}_{2}$ was highest (₹ 31246.08/ha) for Mahreen block while the net return was found to be highest ( $₹ 26224.30 /$ ha) for Akhnoor block with an overall average of ₹ 16398.81 for the two districts. The cost- benefit ratio was found to be highest (1:1.62) for Akhnoor block with an overall ratio of 1:1.36. After calculating the demand and supply in sampled wheat farms, both districts were found to be in surplus stage which was highest in Jammu district (95200kg). On the basis of secondary data it was also found that Jammu and Kathua district had surplus production of wheat, i.e., $5239.46 \mathrm{~kg}, 26447.45 \mathrm{~kg}$, respectively while all other districts of Jammu are deficit. The results regarding trends in productivity growth of the wheat showed that efficiency change ranges between 0.976 to 1.000 for whole decade with a mean value of 0.994 whereas technical change and TFP change was 0.956 for 2016-2017 with a mean of 0.876 and 0.870 , respectively for overall period.

Keywords: CACP, DEAP 2.1, total factor productivity, technical change, surplus, deficit.

Agriculture is an important sector in India. Agricultural growth- throughout global historyhas been the pro-geitor of broad economic growth and development, as linkages between farm- and non-farm economies generated widely based employment, income and growth. On an average, about 70 per cent of the households and 10 per cent of the urban population is dependent on agriculture as their source of livelihood. There has been a continous decline in the share of agriculture and allied sector in the gross value added from 18.6 per cent in 2013-14, 18.0 per cent in $2014-15,17.5$ per cent in $2015-16$ and 17.4 per cent in 2016-17 at current prices (Agriculture How to cite this article: Malik, R., Dwivedi, S., Peshin, R. and Bhat, A.
(2020). Total Factor Productivity and Supply- Demand Gap Analysis of
Wheat in Sub-tropics of Jammu Region of Jammu and Kashmir. Agro
Economist - An International Journal, 7(2): 113-121.
Source of Support: None; Conflict of Interest: None 
Annual Report, 2017-18). In terms of quantity of production, India is the top producer in the world in milk, and second largest in wheat and rice. India being the largest wheat producer in the world, the wheat and wheat flour play an important role in the management of India's food economy (Limbore and Khillare,2015).

Wheat (Triticum aestivum L.) is the world most widely cultivated as a cash crop because it produces a good yield per unit area, grows well in a temperate climate even with a moderately short growing season. Wheat is a rabi crop that is grown in winter season. Sowing of wheat take place in October to December and harvesting is done during the months of February and May. Wheat is an important source of carbohydrates. Wheat grain cantains 8 to 15 per cent protein, 1.5 to 2.5 per cent mineral matter, 2 to 2.6 per cent glucose and 60 to 80 per cent starch. The global wheat production was 755 million metric tons in crop year 2016-2017 (Statista, 2017). India is the second largest producer of wheat after China. In India area and production under wheat cultivation is 295.76 lakh hectare and 99.70 million metric tonnes respectively (DOACFW, 2019). In J\&K, the area under wheat cultivation is 281.87 thousand hectare with a production of 3143 thousand quintals ((DES J\&K, 2016). In Jammu division, the area and production under wheat cultivation is 79.936 thousand hectare and 2041.342 thousand quintals, respectively (DES, Jammu Division, 2017).

In economics, the total factor productivity (TFP), also known as the multifactor productivity is that part of output growth that cannot be explained by the primary inputs of production. If all inputs are accounted for, total factor productivity (TFP) can be taken as a measure of the economy's long term technological change or technological dynamics. The investigation on total factor productivity growth is useful for identifying sources of output growth in the development (Mustapha et al. 2013). Economists have recognized long back that total factor productivity is an important factor in the process of economic growth (Hulten, 2000). Total factor productivity (TFP) is a measure of productivity calculated by dividing economy-wide total production by the weighted average of inputs i.e. labour and capital. It represents growth in real output which is in excess of the growth in inputs such as labour and capital.
The study of cost and return is a major economic analysis so as to find out the financial viability of any crop enterprise. The farming practices have been changing with the introduction of technologies either in the form of variety, cultivation methods and mechanization. Therefore, it is of prime importance to analyze the components of costs and returns also of wheat cultivation with the different levels of mechanization. The Supply-Demand gap analysis is based on total production, consumer requirement per person per day and the total population of the area. It is represented by the interaction of the demand and the supply curves. The present study is conducted to examine the cost and return structure of wheat cultivation, to work out the total factor productivity of rice crop and to analyze gap in supply and demand of wheat in Jammu region.

\section{MATERIALS AND METHODS}

The present study was conducted during the year 2018-19 in sub-tropics of Jammu and Kathua districts of J\&K UT. The districts were selected purposively on the basis of highest area under wheat cultivation. A stratified multistage sampling technique was used. Two blocks each were selected from both districts on the basis of highest area under wheat to constitute four blocks in total and three villages were selected randomly to constitute a total of 12 villages in all Then, 10 farmers were selected randomly from each village so as to constitute a sample size of 120 farmers.

\section{For estimating the costs and returns}

The cost and returns analysis was worked out using CACP cost concepts like cost $\mathrm{A}_{1}$, cost $\mathrm{A}_{2}$, cost $\mathrm{B}_{1}$, cost $\mathrm{B}_{2^{\prime}} \operatorname{cost} \mathrm{C}_{1}, \operatorname{cost} \mathrm{C}_{2}$ and $\operatorname{cost} \mathrm{C}_{3}$

Cost $\mathrm{A}_{1}$ includes:

1. Wages of hired human labour

2. Value of hired bullock labour*

3. Value of owned bullock labour*

4. Value of owned machinery labour

5. Hired machinery charges

6. Value of seed (both farm produced and purchased)

7. Value of insecticides and pesticides

8. Value of manure (owned and purchased) 
9. Value of fertilizer

10. Depreciation on implements and farm buildings

11. Irrigation charges

12. Land revenue, cesses and other taxes

13. Interest on working capital

14. Miscellaneous expenses

Cost $A_{2}$ : Cost $A_{1}+$ rent paid for leased-in land

Cost $B_{1}$ : Cost $A_{1}+$ interest on the value of owned fixed capital assets (excluding land).

Cost $\mathrm{B}_{2}$ : Cost $\mathrm{B}_{1}+$ rental value of owned land + rent paid for leased in land

Cost $C_{1}$ : Cost B1 + imputed value of family labor

Cost $C_{2}$ : Cost $B_{2}+$ imputed value of family labor

Cost $C_{3}$ : Cost $C_{2}+$ value of management input (10 $\%$ of $\operatorname{Cost} \mathrm{C}_{2}$ )

* bullock labour was not taken in the analysis as bullock labour wasn't used in the study area.

\section{Total Factor Productivity analysis}

The period $t$ Malmquist productivity index is given by:

$$
M^{t}=\frac{D_{0}^{t}\left(x^{t+1}, y^{t+1}\right)}{D_{0}^{t}\left(x^{t}, y^{t}\right)}
$$

i.e., they define their productivity index as the ratio of two output distance functions taking technology at time $t$ as the reference technology. Instead of using period $t^{\prime}$ s technology as the reference technology it is possible to construct output distance functions based on period $(t+1)^{\prime}$ s technology and thus another Malmquist productivity index can be laid down as:

$$
M^{t+1}=\frac{D_{0}^{t+1}\left(x^{t+1}, y^{t+1}\right)}{D_{0}^{t+1}\left(x^{t}, y^{t}\right)}
$$

Fare et al. (1994) attempt to remove the arbitrariness in the choice of benchmark technology by specifying their Malmquist productivity change index as the geometric mean of the two-period indices, that is,
$M_{0}\left(x^{t+1}, y^{t+1}, x^{t}, y^{t}\right)=\left[\left(\frac{D_{0}^{t}\left(x^{t+1}, y^{t+1}\right)}{D_{0}^{t}\left(x^{t}, y^{t}\right)}\right)\left(\frac{D_{0}^{t+1}\left(x^{t+1}, y^{t+1}\right)}{D_{0}^{t+1}\left(x^{t}, y^{t}\right)}\right)\right]^{\frac{1}{2}}$

Using simple arithmetic manipulation, the above equation can be written as the product of two distinct components- technical change and efficiency change (Färe et al. (1994).

$$
\begin{gathered}
M_{0}\left(x^{t+1}, y^{t+1}, x^{t}, y^{t}\right)=\frac{D_{0}^{t+1}\left(x^{t+1}, y^{t+1}\right)}{D_{0}^{t}\left(x^{t}, y^{t}\right)} \\
{\left[\left(\frac{D_{0}^{t}\left(x^{t+1}, y^{t+1}\right)}{D_{0}^{t+1}\left(x^{t+1}, y^{t+1}\right)}\right)\left(\frac{D_{0}^{t}\left(x^{t}, y^{t}\right)}{D_{0}^{t+1}\left(x^{t}, y^{t}\right)}\right)\right]^{\frac{1}{2}}}
\end{gathered}
$$

Where Efficiency Change $=$

$$
\frac{D_{0}^{t+1}\left(x^{t+1}, y^{t+1}\right)}{D_{0}^{t}\left(x^{t}, y^{t}\right)}
$$

Technical Change $=$

$$
\left[\left(\frac{D_{0}^{t}\left(x^{t+1}, y^{t+1}\right)}{D_{0}^{t+1}\left(x^{t+1}, y^{t+1}\right)}\right)\left(\frac{D_{0}^{t}\left(x^{t}, y^{t}\right)}{D_{0}^{t+1}\left(x^{t}, y^{t}\right)}\right)\right]
$$

Hence the Malmquist productivity index is simply the product of the change in relative efficiency that occurred between periods $t$ and $t+1$, and the change in technology that occurred between periods $t$ and $t+1$. A value of Malmquist TFP index equal to one implies there has been no change in total factor productivity across the two time periods, greater than one implies a rise / improvement in TFP and a value less than one is interpreted as a regress in TFP. A similar interpretation applies to the two components as well. The total factor productivity was analyzed using the DEAP 2.1 software.

\section{Supply and demand gap analysis}

The Supply-Demand gap analysis is based on total production, consumer requirement per person per day and the total population of the area. The data on production of wheat was collected from different published sources such as; Economic Survey of India, Digest of Statistics, J\&K etc. The data on demand of rice was compiled on the basis of consumer 
requirement per person per day. Estimated per capita requirement was multiplied by population, and aggregated by sample area to obtain the total demand.

\section{RESULTS AND DISCUSSION}

\section{Economics of wheat cultivation}

The item wise cost of cultivation of wheat of sampled farms is presented in Table 1. It revealed that per hectare total cost of cultivation in Akhnoor and Marh blocks of Jammu district was ₹ 41750.70 and ₹ 44351.05 and in Mahreen and Barnoti blocks of Kathua district was ₹ 46273.08 and ₹ 44996.93 with overall average of ₹ 44342.94 .
Expenditure on human labour, seed and farm yard manure (FYM) were the important component of item wise cost. Similarly rental value of owned land was the most important component of fixed cost. The results further revealed that out of all the inputs used, the expenditure incurred on machine labour was found to be highest with an overall average of ₹ 8724.42/ha which was 39.72 per cent of operational cost 17.35 followed by expenditure incurred on human labour (₹ 5179.76/ha) and manures and fertilizers ( $₹ 3506.61 /$ ha). The item wise cost constituted 58.71 per cent and 48.81 per cent of total cost in Akhnoor and Marh blocks of Jammu district and 49.36 per cent and 41.86 per cent in Mahreen and Barnoti blocks of Kathua district, respectively. However on overall basis, the item wise cost was

Table 1: Item-wise cost of cultivation of wheat on sampled farms under study (₹/ha)

\begin{tabular}{|c|c|c|c|c|c|}
\hline \multirow{2}{*}{ Particulars } & \multicolumn{2}{|l|}{ Jammu } & \multicolumn{2}{|l|}{ Kathua } & \multirow{2}{*}{ Overall Average } \\
\hline & Akhnoor & Marh & Mahreen & Barnoti & \\
\hline \multicolumn{6}{|l|}{ A. Operational Cost } \\
\hline \multicolumn{6}{|l|}{ Machine labour } \\
\hline Owned & 2489.82 & 2271.03 & 2640.52 & 2532.12 & 2483.37 \\
\hline Hired & 7541.32 & 5267.31 & 6843.12 & 5312.47 & 6241.05 \\
\hline Total machine labour & 10031.14 (40.93) & $7538.34(34.82)$ & $9483.64(41.51)$ & $7844.59(41.64)$ & $8724.42(39.72)$ \\
\hline \multicolumn{6}{|l|}{ Human labour } \\
\hline Hired labour & 2476.52 & 2124.42 & 1478.26 & 1072.59 & 1251.65 \\
\hline Family labour & 3842.53 & 3724.26 & 2854.31 & 3146.17 & 3391.81 \\
\hline Total human labour & 6319.05 (25.77) & $5848.68(27.03)$ & 4332.57 (18.96) & $4218.76(22.39)$ & $5179.76(23.58)$ \\
\hline Seed & $2164.38(8.82)$ & $2532.15(11.69)$ & $2134.52(9.34)$ & $2114.12(11.22)$ & $2236.29(10.18)$ \\
\hline Manures and fertilizers & $3732.28(15.23)$ & 3506.25 (16.19) & 4411.59 (19.31) & $2376.34(12.61)$ & $3506.61(15.96)$ \\
\hline Herbicides & $234.19(0.95)$ & $353.46(1.64)$ & $435.61(1.90)$ & $394.56(2.09)$ & $354.45(1.63)$ \\
\hline Pesticides & $220.42(0.89)$ & $350.84(1.62)$ & $285.37(1.24)$ & $358.27(1.90)$ & 303.72 (1.38) \\
\hline Irrigation charges & $42.18(0.19)$ & $39.02(0.18)$ & $34.18(0.14)$ & $72.37(0.38)$ & $46.93(0.23)$ \\
\hline Miscellaneous & $384.15(1.56)$ & $253.27(1.17)$ & 432.63 (1.89) & $392.17(2.08)$ & $365.55(1.66)$ \\
\hline Interest on working capital & $1387.66(5.66)$ & $1225.50(5.66)$ & $1293.00(5.66)$ & $1066.27(5.66)$ & $1243.10(5.66)$ \\
\hline Sub total (A) & 24515.45 & 21650.51 & 22843.11 & 18837.45 & 21961.63 \\
\hline \multicolumn{6}{|l|}{ B. Fixed Costs } \\
\hline Rental value of owned land & 12000 & 16000 & 15000 & 16000 & 14750 \\
\hline Land Revenue & 140.00 & 140.00 & 140.00 & 140.00 & 140.00 \\
\hline Sub -total $(10+11)$ & $12140.00(61.50)$ & $16140.00(55.37)$ & $15140.00(49.54)$ & $16140.00(44.84)$ & $14890.00(52.07)$ \\
\hline Depreciation & $4852.62(36.67)$ & $6248.14(42.51)$ & $7895.21(48.05)$ & $9542.37(52.54)$ & $7134.58(45.65)$ \\
\hline Interest on fixed capital & $242.63(1.83)$ & $312.40(2.12)$ & $394.76(2.41)$ & $477.11(2.62)$ & $356.72(2.28)$ \\
\hline Sub -Total (B) & 17235.25 & 22700.54 & 23429.97 & 26159.48 & 22381.31 \\
\hline Total cost $(\mathrm{A}+\mathrm{B})$ & 41750.70 & 44351.05 & 46273.08 & 44996.93 & 44342.94 \\
\hline
\end{tabular}


₹ 21961.63 per hectare and fixed cost was ₹ 22381.31per hectare which constituted 49.52 per cent and 50.47 per cent of total costs, respectively.

In order to view of the cost of cultivation of wheat, various cost concepts were worked out on per hectare basis and are presented in Table 2 .

The per hectare cost $\mathrm{A}_{1}$ on the farms of Akhnoor, Marh, Mahreen and Barnoti were ₹ 25525.54, ₹ 24171.39,
₹ 27857.01 and $₹ 25233.67$ with an overall average of ₹ 25696.90. Cost $A_{2}$ on the farms of Akhnoor, Marh, Mahreen and Barnoti were ₹ 25525.54, ₹ 24171.39, $₹ 27857.01$ and ₹ 25233.67 with an overall average of ₹ 25696.90 respectively. Similarly, per hectare cost $B_{1}$ was ₹ 25768.17, ₹ 24483.79, ₹ 28251.77 and ₹ 25710.78 in Akhnoor, Marh, Mahreen and Barnoti blocks of Jammu and Kathua district, respectively with an overall average of ₹ 26053.62/ha whereas

Table 2: Concept- wise cost of cultivation of wheat on sampled rice farm under (₹/ ha)

\begin{tabular}{|c|c|c|c|c|c|}
\hline \multirow{2}{*}{ Particulars } & \multicolumn{2}{|c|}{ Jammu } & \multicolumn{2}{|c|}{ Kathua } & \multirow{2}{*}{$\begin{array}{l}\text { Overall } \\
\text { Average }\end{array}$} \\
\hline & Akhnoor & Marh & Mahreen & Barnoti & \\
\hline \multicolumn{6}{|l|}{ Cost- $\mathrm{A}_{1}$} \\
\hline Hired labour & 2476.52 & 2124.42 & 1478.26 & 1072.59 & 1251.65 \\
\hline Machine labour & 10031.14 & 7538.34 & 9483.64 & 7844.59 & 8724.05 \\
\hline Seed & 2164.38 & 2532.15 & 2134.52 & 2114.12 & 2236.29 \\
\hline Manures and fertilizers & 3732.28 & 3506.25 & 4411.59 & 2376.34 & 3506.61 \\
\hline Herbicides & 234.19 & 353.46 & 435.61 & 394.56 & 354.45 \\
\hline Pesticides & 220.42 & 350.84 & 258.37 & 358.29 & 303.72 \\
\hline Irrigation charges & 42.18 & 39.02 & 34.18 & 72.37 & 46.93 \\
\hline Miscellaneous & 384.15 & 253.27 & 432.63 & 392.17 & 3655.55 \\
\hline Interest on working capital & 1387.66 & 1225.50 & 1293.00 & 1066.27 & 1243.10 \\
\hline Depreciation charges & 4852.62 & 6248.14 & 7895.21 & 9542.37 & 7134.58 \\
\hline Total cost $-\mathrm{A}_{1}$ & 25525.54 & 24171.39 & 27857.01 & 25233.67 & 25696.90 \\
\hline \multicolumn{6}{|l|}{ Cost- $A_{2}$} \\
\hline Cost $-\mathrm{A}_{1}$ & 25525.54 & 24171.39 & 27857.01 & 25233.67 & 25696.90 \\
\hline Rent paid for leased in land & 0 & 0 & 0 & 0 & 0 \\
\hline Total cost $-\mathrm{A}_{2}$ & 25525.54 & 24171.39 & 27857.01 & 25233.67 & 25696.90 \\
\hline Cost- $\mathrm{B}_{1}$ & & & & & \\
\hline Cost- $\mathrm{A}_{1}$ & 25525.54 & 24171.39 & 27857.01 & 25233.67 & 25696.90 \\
\hline Interest on fixed capital (excluding land) & 242.63 & 312.40 & 394.76 & 477.11 & 356.72 \\
\hline Total cost- $\mathrm{B}_{1}$ & 25768.17 & 24483.79 & 28251.77 & 25710.78 & 26053.62 \\
\hline \multicolumn{6}{|l|}{ Cost- $B_{2}$} \\
\hline Cost- $\mathrm{B}_{1}$ & 25768.17 & 24483.79 & 28251.77 & 25710.78 & 26053.62 \\
\hline Rental value of owned land & 140.00 & 140.00 & 140.00 & 140.00 & 140.00 \\
\hline Rent paid for leased in land & 0 & 0 & 0 & 0 & 0 \\
\hline Total cost- $\mathrm{B}_{2}$ & 25908.17 & 24623.79 & 28391.77 & 25850.78 & 26193.62 \\
\hline \multicolumn{6}{|l|}{ Cost- $\mathrm{C}_{1}$} \\
\hline Cost-B & 25768.17 & 24483.79 & 28251.77 & 25710.78 & 26053.62 \\
\hline Family labour & 3842.53 & 3724.26 & 2854.31 & 3146.17 & 3391.81 \\
\hline Total cost- $\mathrm{C}_{1}$ & 29610.70 & 28208.05 & 31106.08 & 28856.95 & 29445.44 \\
\hline \multicolumn{6}{|l|}{ Cost- $\mathrm{C}_{2}$} \\
\hline Cost- $\mathrm{B}_{2}^{2}$ & 25908.17 & 24623.79 & 28391.77 & 25850.78 & 26193.62 \\
\hline Family labour & 3842.53 & 3724.26 & 2854.31 & 3146.17 & 3391.81 \\
\hline Total cost- $\mathrm{C}_{2}$ & 29750.70 & 28348.05 & 31246.08 & 28996.95 & 29585.44 \\
\hline \multicolumn{6}{|l|}{ Cost- $\mathrm{C}_{3}$} \\
\hline Cost- $\mathrm{C}_{2}$ & 29750.70 & 28348.05 & 31246.08 & 28996.95 & 29585.44 \\
\hline Cost of management $\left(10 \%\right.$ of Cost- $\left.\mathrm{C}_{2}\right)$ & 2975.07 & 2834.80 & 3124.60 & 2899.69 & 2958.54 \\
\hline Total cost- $\mathrm{C}_{3}$ & 32725.77 & 31182.85 & 34370.68 & 31896.64 & 32543.98 \\
\hline
\end{tabular}


cost $B_{2}$ was ₹ 25908.17and ₹ 24623.79 for Akhnoor and Marh block and ₹ 28391.77 and ₹ 25850.78 for Mahreen and Barnoti block of Kathua district with an overall average of ₹ 26193.62. The per hectare cost $C_{1}$ was ₹ 29610.70, ₹ 28208.05, ₹ 31106.08 and ₹ 28856.95 of Akhnoor, Marh, Mahreen and Barnotiblock of Jammu and Kathua district with an overall average of ₹ 33450.44. The per hectare cost $C_{2}$ for Akhnoor and Marh block of Jammu district along with Mahreen and Barnoti block of Kathua district was found to ₹ 29750.70, ₹ 28348.05, ₹ 31246.08 and ₹ 28996.95 with an overall average of ₹ 29585.44, respectively. After working out manageria cost, i.e., 10 per cent of cost $\mathrm{C}_{2}$, per hectare cost $\mathrm{C}_{3}$ found to be $₹ 32725.77$, ₹ 31182.85, ₹ 34370.68, and ₹ 31896.64 in Akhnoor. Marh, Mahreen and Barnoti block, respectively with an overall average of ₹ 32543.98 on all farms.
Cost concept wise economics of wheat is presented in Table 3 which revealed that per hectare overall net returns of wheat cultivation over cost $A_{1}$, cost $\mathrm{A}_{2}, \cos t \mathrm{~B}_{1^{\prime}} \cos t \mathrm{~B}_{2^{\prime}}$ cost $\mathrm{C}_{1}$, cost $\mathrm{C}_{2}$ and cost $\mathrm{C}_{3}$ were ₹ 35044.83/ha, ₹ 35044.83/ ha, ₹ 34688.13/ha, ₹ 34548.13/ha, ₹ 31296.31/ha, ₹ 31156.31/ ha and ₹ $28197.77 /$ ha respectively. The return per rupee investment on all farms over cost $\mathrm{A}_{1}, \operatorname{cost} \mathrm{A}_{2^{\prime}}$ cost $\mathrm{B}_{1^{\prime}}$ $\operatorname{cost} B_{2}, \operatorname{cost} C_{1}, \operatorname{cost} C_{2}$ and $\operatorname{cost} C_{3}$ were $₹ 2.36$, ₹ 2.36, ₹ 2.33 , ₹ 2.31, ₹ 2.06, ₹ 2.05 and ₹ 1.86, respectively.

On the basis of $\operatorname{cost} \mathrm{C}_{2}$ returns per rupee were highest for farms of Akhnoor block (₹ 2.28) followed by Marh (₹ 2.15), Marheen (₹ 1.90) and least in Barnoti (₹ 1.86) with an overall average of ₹ 2.05. The Malmquist productivity indices estimated are presented in Table 4.

Table 3: Productivity, income and cost concept wise economics of wheat cultivation

\begin{tabular}{|c|c|c|c|c|c|}
\hline \multirow{2}{*}{ Particulars } & \multicolumn{2}{|c|}{ Jammu } & \multicolumn{2}{|c|}{ Kathua } & \multirow{2}{*}{$\begin{array}{l}\text { Overall } \\
\text { Average }\end{array}$} \\
\hline & Akhnoor & Marh & Mahreen & Barnoti & \\
\hline Yield per ha (q) & 30.15 & 28.12 & 26.54 & 24.12 & 27.23 \\
\hline Gross income (₹/ha) & 67975.00 & 61182.00 & 59630.00 & 54180.00 & 60741.75 \\
\hline \multicolumn{6}{|c|}{ Net return over different costs (₹/ha) } \\
\hline Cost $A_{1}$ & 42449.46 & 37010.61 & 31772.99 & 28946.33 & 35044.83 \\
\hline Cost $\mathrm{A}_{2}$ & 42449.46 & 37010.61 & 31772.99 & 28946.33 & 35044.83 \\
\hline Cost $\mathrm{B}_{1}^{2}$ & 42206.83 & 36698.21 & 31378.23 & 28469.22 & 34688.13 \\
\hline Cost $B_{2}$ & 42066.83 & 36558.21 & 31238.23 & 28329.22 & 34548.13 \\
\hline $\operatorname{Cost} C_{1}^{2}$ & 38364.30 & 32973.95 & 28523.92 & 25323.05 & 31296.31 \\
\hline $\operatorname{Cost} C_{2}^{1}$ & 38224.30 & 32833.95 & 28383.92 & 25183.05 & 31156.31 \\
\hline $\operatorname{Cost} C_{3}^{2}$ & 35249.23 & 29999.15 & 25259.32 & 22283.36 & 28197.77 \\
\hline \multicolumn{6}{|c|}{ Cost benefit ratio over different costs } \\
\hline Cost $\mathrm{A}_{1}$ & $1: 2.66$ & $1: 2.53$ & $1: 2.14$ & $1: 2.14$ & $1: 2.36$ \\
\hline Cost $A_{2}$ & 1:2.66 & $1: 2.53$ & $1: 2.14$ & 1:2.14 & $1: .2 .36$ \\
\hline Cost $B_{1}^{2}$ & $1: 2.63$ & $1: 2.49$ & 1:2.11 & 1:2.10 & $1: 2.33$ \\
\hline Cost $B_{2}$ & $1: 2.62$ & $1: 2.48$ & 1:2.10 & 1:2.09 & 1:2.31 \\
\hline $\operatorname{Cost} C_{1}^{2}$ & 1:2.29 & $1: 2.16$ & $1: 1.91$ & $1: 1.87$ & $1: 2.06$ \\
\hline Cost $C_{2}^{1}$ & $1: 2.28$ & 1:2.15 & $1: 1.90$ & 1:1.86 & 1:2.05 \\
\hline $\operatorname{Cost} C_{3}^{2}$ & $1: 2.07$ & 1:1.96 & $1: 1.73$ & $1: 1.69$ & 1:1.86 \\
\hline
\end{tabular}

Table 4: Summary of Malmquist Productivity Indices for wheat and year wise decomposition

\begin{tabular}{llllll}
\hline Year & Efficiency change & Technical change & Pure change & Scale change & TFP change \\
\hline $2007-08$ & 0.998 & 0.901 & 0.998 & 1.000 & 0.899 \\
$2008-09$ & 0.987 & 0.845 & 0.987 & 1.000 & 0.834 \\
$2009-10$ & 1.000 & 0.812 & 1.000 & 1.000 & 0.812 \\
$2010-11$ & 1.000 & 0.899 & 1.000 & 1.000 & 0.899 \\
$2011-12$ & 1.000 & 0.923 & 1.000 & 1.000 & 0.923 \\
$2012-13$ & 0.976 & 0.905 & 0.976 & 1.000 & 0.883 \\
$2013-14$ & 0.982 & 0.812 & 0.982 & 1.000 & 0.797 \\
$2014-15$ & 1.000 & 0.824 & 1.000 & 1.000 & 0.824 \\
$2015-16$ & 1.000 & 0.889 & 1.000 & 1.000 & 0.889 \\
$2016-17$ & 1.000 & 0.956 & 1.000 & 1.000 & 0.956 \\
Mean & 0.994 & 0.876 & 0.994 & 1.000 & 0.870 \\
\hline
\end{tabular}

Source: Indiastat, IASRI, FCI. 


\section{Total Factor Productivity}

The trends in productivity growth of wheat (Table 5) showed that during the year 2007-08, the total factor productivity change (TFP) in case of wheat was recorded to be 0.899 with efficiency change 0.998 (pure change 0.998 and scale change 1.000) and technical change 0.901. During year 2008-09 and 2009-10 TFP decreased to 0.834 and 0.812 whereas the technical change also decreased to 0.845 and 0.812 . However, for 2010-11 and 2011-12 there is an increase in TFP change of 0.899 and marginal increase of 0.923. Year 2012-13 and 2013-14 observed a decrease in TFP with the value of 0.883 and 0.797 . The year 2014-15, the TFP change and technical change was 0.824 while for year 2015-16, there is a marginal increase in TFP with a value of 0.889 . The TFP change was highest for the year 206-17 i.e., 0.956 with a similar technical change and this was mainly due to increased use of technology at the farms. However, for overall period, TFP change was recorded to be 0.870 with efficiency change of 0.994 (pure change 1.000 and scale change 1.000) and technical change of 0.876 .

The Table 5 represents the supply demand gap analysis in sampled wheat farms in Jammu and Kathua. It was revealed that the Baisa Chak, Barula, Muthi villages of the Akhnoor block has per household consumption of $13700 \mathrm{~kg}, 18900 \mathrm{~kg}$ and $29100 \mathrm{~kg}$ per year with per capita consumption of $224.59 \mathrm{~kg}, 187.12 \mathrm{~kg}$ and $510.52 \mathrm{~kg}$ per year. The production of wheat in these respective villages was calculated to be $24200 \mathrm{~kg}$, $48200 \mathrm{~kg}$ and 38400 $\mathrm{kg}$ with a surplus of $10500 \mathrm{~kg}, 29300 \mathrm{~kg}$ and 9300 $\mathrm{kg}$, respectively. Thus, the sampled wheat farms in the Akhnoor block have a surplus production of wheat. Similarly, in Marh block, the villages, Bullat Chak, Marh and Poni Chak village too have a surplus production of $8700 \mathrm{~kg}, 25500 \mathrm{~kg}$ and 11900 $\mathrm{kg}$. It has been revealed that the sampled wheat farms in Jammu district have a surplus production of wheat. The Bauhra and Nannan villages of the Barnoti block of Kathua district has per household consumption of $11800 \mathrm{~kg}$ and $4700 \mathrm{~kg}$ while the Falote village was deficit in production per year with per capita consumption of $222.95 \mathrm{~kg}, 259.18 \mathrm{~kg}$ and $228.81 \mathrm{~kg}$ per year while the production in Bauhra, Falote and Nannan villages was 25400 kg, $3100 \mathrm{~kg}$ and $18200 \mathrm{~kg}$ respectively with a surplus of 11800 $\mathrm{kg}, 4700 \mathrm{~kg}$ in Bauhra and Nannan respectively and Nannan was deficit in wheat productivity. Thus the sampled wheat farms of Barnoti block have a surplus production. Even in the Marheen block, the sampled farms in the Mathwar, Ladwali and Rakh Sarkar village have a surplus of $24100 \mathrm{~kg}, 8800 \mathrm{~kg}$

Table 5: Supply and demand gap analysis in sampled wheat farms in Jammu and Kathua districts

\begin{tabular}{|c|c|c|c|c|c|c|c|}
\hline \multirow[b]{2}{*}{ District } & \multirow[b]{2}{*}{ Block } & \multirow[b]{2}{*}{ Village } & \multirow[b]{2}{*}{$\begin{array}{l}\text { Total family } \\
\text { size }\end{array}$} & \multicolumn{2}{|c|}{ Consumption (kg) } & \multirow[b]{2}{*}{$\begin{array}{l}\text { Production } \\
\text { (kg) }\end{array}$} & \multirow[b]{2}{*}{$\begin{array}{l}\text { Surplus } \\
\text { (kg) }\end{array}$} \\
\hline & & & & $\begin{array}{l}\text { Per household } \\
\text { per year }\end{array}$ & $\begin{array}{l}\text { Per head per } \\
\text { year }\end{array}$ & & \\
\hline \multirow[t]{7}{*}{ Jammu } & Akhnoor & Baisa Chak & 61 & 13700 & 224.59 & 24200 & 10,500 \\
\hline & & Barula & 101 & 18900 & 187.12 & 48200 & 29,300 \\
\hline & & Muthi & 57 & 29100 & 510.52 & 38400 & 9,300 \\
\hline & Marh & Bullay Chak & 54 & 6800 & 161.90 & 15,500 & 8,700 \\
\hline & & Marh & 70 & 9400 & 134.28 & 34900 & 25,500 \\
\hline & & Poni Chak & 59 & 14,000 & 237.28 & 25900 & 11900 \\
\hline & Total & & & & & & 95200 \\
\hline \multirow[t]{7}{*}{ Kathua } & Barnoti & Bauhra & 61 & 13600 & 222.95 & 25400 & 11800 \\
\hline & & Falote & 49 & 12,700 & 259.18 & 3,100 & -9600 \\
\hline & & Nannan & 59 & 13,500 & 228.81 & 18,200 & 4,700 \\
\hline & Marheen & Mathwar & 58 & 8600 & 148.27 & 32700 & 24,100 \\
\hline & & Ladwal & 71 & 11800 & 166.19 & 20600 & 8,800 \\
\hline & & Rakh Sarkar & 53 & 14100 & 266.03 & 19600 & 5,500 \\
\hline & Total & & & & & & 54,900 \\
\hline
\end{tabular}


Table 6: District wise supply and demand gap analysis of Jammu region

\begin{tabular}{lllllll}
\hline District & Population & $\begin{array}{l}\text { Area under } \\
\text { wheat (ha) }\end{array}$ & $\begin{array}{l}\text { Demand } \\
\text { (tonnes) }\end{array}$ & $\begin{array}{l}\text { Supply } \\
\text { (tonnes) }\end{array}$ & $\begin{array}{l}\text { Area irrigated } \\
\text { (ha) }\end{array}$ & $\begin{array}{l}\text { Surplus } \\
\text { (tonnes) }\end{array}$ \\
\hline Jammu & 1529958 & 79936 & 198894.54 & 204134 & 43400 & 5239.46 \\
Samba & 319000 & 29549 & 41470.00 & 55357 & 9700 & 13887 \\
Kathua & 616435 & 50195 & 80136.55 & 106584 & 18000 & 26447.45 \\
Udhampur & 555357 & 36906 & 72196.41 & 57456 & 2000 & -14740.41 \\
Reasi & 314667 & 14232 & 40906.71 & 23762 & 600 & -17144.71 \\
Ramban & 283713 & 5416 & 36882.69 & 47318 & 100 & 10435.31 \\
Kishtwar & 230696 & 2405 & 29990.48 & 4615 & 600 & -25375.48 \\
Doda & 409936 & 3357 & 53291.68 & 4186 & 200 & -49105.68 \\
Rajouri & 642415 & 45587 & 83513.95 & 60123 & 3300 & -23390.95 \\
Poonch & 476835 & 14956 & 61988.55 & 21296 & 1800 & -40692.55 \\
\hline Total & 5379012 & 282539 & 699271.56 & 542248 & 79700 & 226459.00 \\
\hline
\end{tabular}

and $5500 \mathrm{~kg}$. Therefore, the sampled wheat farms in both the districts have a surplus production of wheat i.e., $95200 \mathrm{~kg}$ and $54900 \mathrm{~kg}$ for Jammu and Kathua districts respectively except the village Falote was deficit in wheat production. This also confirms that Jammu and Kathua districts have surplus wheat.

The trend in requirement for wheat as direct demand was highest (198894.54 tonnes) in Jammu district followed by Rajouri (83513.95 tonnes) whereas least in Kishtwar (29990.48 tonnes). The requirement is calculated on the basis of population as per 2011 census. By multiplying the per capita requirement as per the $11^{\text {th }}$ five year plan of the planning commission with total population of the district, we arrived at the direct household demand for different districts. It has been revealed that Jammu leads the total of the district with highest production of wheat (204134 tonnes) whereas Doda shows lowest production of wheat (4186 tonnes) as per the Regional Digest of Statistics, Jammu Division, 2016-17 (Table 6).

It has been observed that Jammu, Samba, Kathua and Ramban district have surplus wheat whereas other districts were deficit in wheat. Jammu region as a whole is also found to be deficit in wheat with requirement of 226459.00 tonnes.

\section{CONCLUSION}

The cost of wheat cultivation in Jammu sub-tropics was found to be ₹ 44342.94/ha. Out of all the inputs used, the expenditure incurred on the machine labour was found to be highest with an overall average of ₹ 8724.72/ ha which was 39.72 per cent of operational because the farmers were using machines for major operations like land preparation, harvesting, threshing and winnowing. The machine labour was followed by expenditure incurred on human labour, both hired and family labour (₹ 5179.76/ ha) and manures and fertilizers (₹ 3506.61/ha). The cost structure revealed that $\operatorname{cost} \mathrm{A}_{1^{\prime}}$ cost $\mathrm{A}_{2^{\prime}}$ cost $\mathrm{B}_{1^{\prime}}$ cost $B_{2^{\prime}}$ cost $C_{1}$, cost $C_{2^{\prime}}$ cost $C_{3}$ were $₹ 25696.90 /$ ha, ₹ 25696.90/ha, ₹ 26053.62/ha, ₹ 26193.62/ ha, ₹ 29445.44/ha, ₹ 29585.44/ha, ₹ 32543.98/ha respectively and per hectare net returns obtained over $\mathrm{A}_{1}$, cost $\mathrm{A}_{2}$, cost $\mathrm{B}_{1} \operatorname{cost} \mathrm{B}_{2}$, cost $\mathrm{C}_{1}, \operatorname{cost} \mathrm{C}_{2}$, cost $\mathrm{C}_{3}$ were, ₹35044.83, ₹ 35044.83, ₹ 34688.13, ₹34548.13, $₹ 31296.31$, ₹ 31156.31 and $₹ 28197.77$, respectively. The return per rupee investment on all farms over $\operatorname{cost} \mathrm{A}_{1}$, cost $\mathrm{A}_{2}$, cost $\mathrm{B}_{1}$, cost $\mathrm{B}_{2}, \cos t \mathrm{C}_{1}, \cos t \mathrm{C}_{2}$ and cost $C_{3}$ were ₹ 2.36 , ₹ 2.36 , ₹ 2.33 , ₹ 2.31 , ₹ 2.06 , ₹ 2.05 and $₹ 1.86$, respectively. The main conclusion of the study is that although technological progress has contributed mainly to the total productivity growth of wheat production for the period under study, it has been uneven and even less than one. Again in the year 2016-17 TFP growth has less than one i.e., 0.956 due to surge in the technological change supported by matured and/or sustained public R\&D, extension, supplies of new inputs including irrigation, power, and credit, besides input subsidies and private investment by the farmers The decline in the TFP growth in was mainly due to dwindling technical 
progress in the those years. The increase or decrease in the TFP growth is mainly due to the increase or decrease in the technical change rather than due to technical efficiency. However, the low PECH (pure efficiency change) in comparison to SECH (scale efficiency change) suggests that inefficiency is mostly due to inefficient wheat production practices. For wheat production growth to sustain in the future, the Indian government might need to look more carefully into the factors that have caused such a serious decline in the technical progress. The supply demand gap analysis showed that the surplus was calculated to be $95200 \mathrm{~kg}$ for the Jammu district and $54900 \mathrm{~kg}$ for the Kathua district, respectively. The trend in requirement for wheat as direct demand was highest (198894.54 tonnes) in Jammu district followed by Rajouri (83513.95 tonnes) whereas least in Kishtwar (29990.48 tonnes). It was found that Jammu leads the tally of the district with highest production of wheat (204134.00 tonnes) whereas Doda shows lowest production of wheat (4186 tonnes) and finally it was found that Jammu, Samba, Kathus and Ramban district have surplus wheat whereas other districts were deficit in wheat. Jammu region as a whole is also found to be deficit in wheat with requirement of 226459.00 tonnes.

\section{REFERENCES}

Cororaton, C.B. 2002. Total Factor Productivity in the Philippines. Discussion paper series no. 2002-01, Philippine Institute for Development Studies, Suriansamga Pag-aaral Pangkaunlaranng Pilipina.

DES J\&K. 2016. Digest of Statistics. Directorate of Economics and Statistics, Government of Jammu and Kashmir.

DES Jammu region. 2017. Regional Digest of Statistics, Jammu division. Directorate of Economics and Statistics, Government of Jammu and Kashmir.

DOACFW, 2019. $2^{\text {nd }}$ Advance Estimates of Production of Major Crops for 2018-19. Department of Agriculture, Cooperation \& Farmer Welfare, Ministry of Agriculture \& Family Welfare, Government of India. pib.nic.in/ newsite/Print Release.aspx?relid=189003. Accessed on 06.06.2019.

Dwivedi, S., Dwivedi, M.C. and Singh, T. 2011. An Economic Analysis of Basmati Rice Production in Jammu District of Jammu and Kashmir. Journal of Research, SKUAST-J, 10(1): 93-99.
Fan, S., Hazell, P.B.R. and Thorat, S. 1999. Linkages between government spending, growth and poverty in rural India. Research Report No. 110. IFPRI, Washimgton, D.C.

Farooq, U., Young, T., Russell, N. and Iqbal, M. 2001. The supply response of basmati rice growers in Punjab, Pakistan: Price and non- price determinants. Journal of International Development, 13: 227-337.

FCI, 2019. https:// www.fci.gov.in/procurements. php?view=89. Accessed on 08.05.2019.

IASRI Databook, 2018. pp. 109. https://iasri.icar.gov.in/ agridata/. Accessed on 08.05.2019.

Indiastat. https:/ / www.indiastat.com/agriculture-data/2/ stats.aspx. Accessed on 08.05.2019.

Kachroo, J. and. Kachroo, D. 2007. Economic Analysis of Fine Rice Production under Subtropical Agro-climatic Zone of Jammu Region of Jammu and Kashmir State. Agricultural Situation in India, 8(2): 413-417.

Kumar, P., Kumar, A. and Mittal, S. 2004. Total factor productivity of crop sector in the Indo-Gangetic Plain of India: Sustainability Issue Revisited. Indian Economic Review, 39(1): 169-201.

Planning Commission, 2012. $11^{\text {th }}$ Five year plan. Government of India. 2. https:/ / www.google.com/search?q=11th + five+year+plan\&oq +11 th+five $+\& a q s=$ chrome $.0 .69 \mathrm{i} 59 \mathrm{j}$ 69i57j012.6184j0j7. Accessed on 09-05-2019.

Prasad, V.R., Govardhan, M. and Mohammad, S. 2010. Economic analysis of rice cultivation in NSP Left Canal command area. Agricultural Situation in India, 66(12): 723-725.

Sehar, H. 2013. Productivity and sustainability measurement of cropping system in Jammu. Ph.D. thesis. SKUAST-J, Jammu, India.

Sindhu, D.S. and Byerlee. D. 1991. Technical change and wheat productivity in Post- Green Revolution in Punjab, India. Economic and Political Weekly, 26(52): 159-166.

Statista, 2017. https:/ / www.statista.com/topics/1443/rice/. Accessed on 06.06.2019.

Suresh, A. and Reddy, T.R.K. 2006. Resource- use efficiency of paddy cultivation in Peechi command area of Thrissur district of Kerala: An Economic Analysis. Agricultural Economics Research Review, 19(1): 159-171.

Tomar, R.K.S. 1994. Import of first line demonstration on the productivity and profitability of pulses and oilseeds crop in Bundel-khand zone of Madhya Pradesh. Advance Agricultural Research in India, 1(1): 133. 
